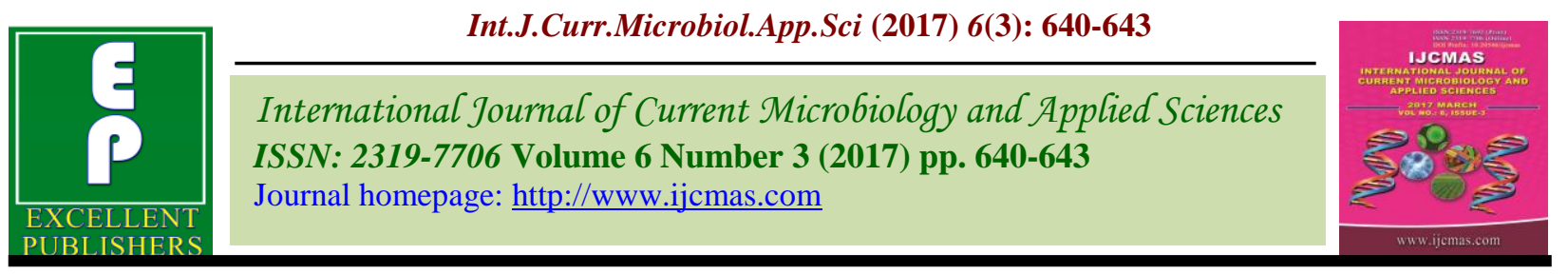

Case Study https://doi.org/10.20546/ijcmas.2017.603.074

\title{
Investigation of Dermatophytosis from the Skin Scrapings Collected from a Cow: A Case Study
}

\section{Subha Ganguly ${ }^{1}$, Parveez Ahmad Para ${ }^{2}$ and Praveen Kumar Praveen ${ }^{3}$}

\begin{abstract}
${ }^{1}$ Department of Veterinary Microbiology, Arawali Veterinary College (affiliated with Rajasthan University of Veterinary and Animal Sciences, Bikaner), N.H. - 52 Jaipur Road, V.P.O. Bajor, Sikar - 332001, Rajasthan, India

${ }^{2}$ Department of Livestock Products Technology, Arawali Veterinary College (affiliated with Rajasthan University of Veterinary and Animal Sciences, Bikaner), N.H. - 52 Jaipur Road, V.P.O. Bajor, Sikar - 332001, Rajasthan, India

${ }^{3}$ Department of Veterinary Public Health and Epidemiology, Arawali Veterinary College (affiliated with Rajasthan University of Veterinary and Animal Sciences, Bikaner), N.H. - 52 Jaipur Road, V.P.O. Bajor, Sikar - 332001, Rajasthan, India

*Corresponding author
\end{abstract}

\begin{tabular}{|c|c|}
\hline & A B S T R A C T \\
\hline \multicolumn{2}{|l|}{ Keywords } \\
\hline $\begin{array}{l}\text { Dermatophytes, } \\
\text { Fungus, Skin } \\
\text { scraping. }\end{array}$ & \multirow{4}{*}{$\begin{array}{l}\text { Dermatophytosis is a superficial infection of the keratinized layers of the } \\
\text { skin and its appendages (hair, feathers, horns) of farm, domesticated and } \\
\text { wild animals and birds. The lesions are frequently ring shaped, hence the } \\
\text { disease is called ring worm. The present article reports on the laboratory } \\
\text { examination of skin scraping sample collected from a cow clinically } \\
\text { infected with dermatophyte infection. }\end{array}$} \\
\hline Article Info & \\
\hline $\begin{array}{l}\text { Accepted: } \\
\text { 10 February } 2017 \\
\text { Available Online: }\end{array}$ & \\
\hline 10 March 2017 & \\
\hline
\end{tabular}

\section{Introduction}

Some dermatophytes have great zoonotic importance, where many of them occurring primarily in animals and can be transmitted from infected animals to man (Nakamura et $a l .$, 1999). Dermatophytes are filamentous fungi which invade keratinized tissues of humans and animals, causing mild to severe, localized and/or diffuse infections. Zoophilic and Geophilic dermatophytes infect both animals and humans, whereas anthropophilic ones are mainly found on humans (Cafarchia et al., 2013). Dermatophytosis, caused by Trichophyton verrucosum is a disease that affects many species of livestock and occurs in acute or chronic forms. It is believed that the prolonged wetting is thought to be important predisposing factors (Moretti et al., 1998; Papini et al., 2009). Affected animals initially develop characteristic discrete, scaly patches of hair loss with grey-white crust that later become thickly suppurated crust with highly variable locations (Radostits et al., 
2000). It is caused by haematogenous group of keratinophylic fungi called the dermatophytes. Dermatophytes are noninvasive cannot survive in living tissues nor in areas of intense inflammation and they have keratolytic activity. Infection is generally restricted to the non-living cornified layers. Dermatophytosis is a clinical entity caused by the members of anamorph genera Microsporum, Trichophyton and Epidermophyton (Weitzman and Summerbell, 1995; Ainswoth GC, Austwick, 1973; Balows et al., 1990; Ganguly et al., 2015; Ganguly et al., 2017; Ganguly and Sharma, 2017).

In addition to the dermatophytic fungi, other yeasts and molds are sometimes involved in the coetaneous infection (Beneke and Rogers, 1990).

\section{Materials and Methods}

The skin scrapings were collected from the scaly and alopecic lesions on the skin of an affected cow presented for clinical examination at the Teaching Veterinary Clinical Complex (T.V.C.C.) of Arawali Veterinary College, Sikar, during January, 2017. The collected skin scraping samples were then brought to the Department of Veterinary Microbiology for mycological examination and reporting.

The samples were examined by direct microscopical examination by placing the skin scrapings and/or hairs in $20 \% \mathrm{KOH}$ on a glass slide and gentle heating, without boiling. Boiling may cause precipitation and crystal formation that will make examination of specimens difficult (Carter and Cole, 1990). Superchrome blue-black ink or a simple stain mixed 1 part in 9 parts of $\mathrm{KOH}$ was used to examine the fungus elements and spores in scrapings, if any. The cover slip was placed on the preparation and examined under low power magnification.
The sample after incubation in Sabouraud's dextrose broth was then inoculated on Sabouraud's dextrose agar by spread plate method. The acidity of the agar inhibited the growth of most bacteria and encouraged the growth and culture of dermatophytes (Jungerman and Schwartzman, 1972). The dermatophyte identification was made based on the colony characteristics and microscopic features of the fungal isolates according to the methods described by Rippon (1988) and Larone (1995).

\section{Results and Discussion}

The incubated Sabouraud's dextrose broth sample was subjected to spread plate culture on Sabouraud's dextrose agar (SDA) media with chloramphenicol and cyclohexamide. The media was incubated at $27^{\circ} \mathrm{C}$ for two weeks. Staining with crystal violet dye mixed 1 part in 9 parts of $\mathrm{KOH}$ outlined the fungus elements and spores (arthrospores) microscopically in the scrapings. The fungal colonies were obtained on SDA followed by incubation at $35^{\circ} \mathrm{C}$ for 72 hours. It revealed the presence of characteristic colonies spreading in nature with characteristic greyish-white cottony woolly mycelia after incubation. On SDA media, colonies were small, button shaped, white to cream-coloured colonies with a velvety surface, raised centre and flat periphery.

Microscopic examination of the colonies revealed positive mycotic structures spherical, pyriform to calvate often of irregular shape which is characteristic of Trichophyton spp. (Takatori et al., 1993).

Several outbreaks of the disease have been reported in cattle in Kenya (Wabascha et al., 1998) and in China (Ming et al., 2006). The clinical signs observed in the present investigation were similar to the dermatophytosis in cattle as was reported by Chermette et al. (2008). The back and flank 
lesions occurred more frequently than on the other parts of the body. The two sites are more exposed than the other parts of the body and as a result they are more and injuries and therefore predisposing the back and flank to infection by $T$. verrucosum (Swai and Sanka, 2012).

In conclusion, the present study revealed the presence of superficial dermatophyte skin infection in the affected cow. The recommended therapy was suggested to the T.V.C.C. for administration to the camel in divided doses on alternate daily intervals preferably in mixed preparations.

\section{Acknowledgements}

The authors are thankful to Hon'ble Dean and Management (Hony. Chairman and Secretary, Aastha Society, Sikar) of Arawali Veterinary College for providing the necessary facilities to carry out the lab diagnostic work.

\section{References}

Ainswoth, G.C. and Austwick, P.K.C. 1973. Fungal diseases of animals. $2^{\text {nd }}$ ed. Commonwealth Agricultural Bureaux, Farnham, England.

Balows, A., Hansler, W.J., Ohashi, M. and Turano, A. 1990. Laboratory diagnosis of infectious diseases, Principles and Practice. Vol. 1. Bacterial, Mycotic and Parasitic Diseases. Springer-Verlag NY, London, Paris, Tokyo.

Beneke, E.S. and Rogers, A.L. 1980. Medical Mycology Manual. $4^{\text {th }}$ ed. Minneapolis, Burgess.

Cafarchia, C., Iatta, R., Latrofa, M.S., Graser, Y. and Otranto, D. 2013. Molecular epidemiology, phylogeny and evolution of dermatophytes. Inf. Genet. Evol., 20: 336-351.

Carter, G.R. and Cole, J.R. 1990. Diagnostic procedures in veterinary bacteriology and mycology. Academic press, Inc. NY, Boston, London, Sydney, Tokyo, 1990.

Chermette, R., Ferreiro, L. and Guillot, J. 2008. Dermatophytoses in animals. Mycopathologia, 166(5-6): 385-405.

Ganguly, S., Padhy, A., Para, P.A., Sahoo, A., Sharma, S., Pandey, A.K., Praveen, P.K. and Saroj. 2015. Basic guidelines and procedures for the clinical and laboratory diagnosis of Mycotic infections in animals: A general overview of veterinary importance. $J$. Lab. Life Sci., 1(1): 1-10.

Ganguly, S., Para, P.A. and Praveen, P.K. 2017. Dermatophyte examination of skin scrapings collected from camel: a case study. Int. J. Curr. Microbiol. Appl. Sci., 6(2): $\mathrm{xxx}-\mathrm{xxx} . \quad$ doi: http://dx.doi.org/10.20546/ijcmas.2017. 602.0xx (In press for publication in Feb.'17 issue.

Ganguly, S., Para, P.A. and Praveen, P.K. 2017) Dermatophyte examination of skin scrapings collected from camel: a case study. Int. J. Curr. Microbiol. Appl. Sci., 6(2): 1731-34. doi: http://dx.doi.org/10.20546/ijcmas. 2017. 602.193

Ganguly, S. and Sharma, V. 2017. Dermatophytosis in animals: an overview. Pharm. Biol. Evaluations, 4(1): 66-67.

Ganguly, S. and Sharma, V. 2017. Dermatophytosis in animals: an overview. Pharm. Biol. Evaluations, 4(2): Xxx-Xxx (In press for publication in Jan. - Feb.' 17 issue.

Jungerman, P.F. and Schwartzman, R.M. 1972. Vet. Mycol., Philadephia, Lea and Febiger.

Kuttin, E.S., Alhanaty, E., Feldman, M., Chaimovits, M. and Müller, J. 1986. Dermatophytosis of camels. J. Med. Vet. Mycol., 24(4): 341-44.

Larone, D.H. 1995. Medically important 
fungi: a guide to identification. 3rd ed. Washington (DC): ASM Press.

Ming, P.X., Ti, Y.L.X. and Bulmer, G.S. 2006. Outbreak of Trichophyton verrucosum in China transmitted from cows to man. Mycopathologia, 161: 225-228.

Monga, D.P. and Mohapatra, L.N. 1980. A compilation of published reports of mycoses in animals in India. Mycopathologia, 72: 3-11.

Moore, G.S. and Jaciow, D.M. 1979. Mycology for the clinical laboratory. Reston Publishing Co., Inc, Reston, Virginia.

Moretti, A., Boncio, L., Pasquali, P. and Fioretti, D.P. 1998. Epidemiological aspects of dermatophyte infections in horses and cattle. Zentralbl Veterinarmed. B, 45(4): 205-208.

Mukherji, K.G., Srivastava, K., Singh, K.P. and Garg, K.L. 1992. Adv. Med. Mycol., Aditya Books Pvt. Ltd., New Delhi.

Nakamura, Y., Watanabe, S. and Hasegawa, A. 1999. Dermatomycosis in human and animals. Nippon Ishinkin Gakkai Zasshi, 40: 9-14.

Papini, R., Nardoni, S., Fanelli, A. and Mancianti, F. 2009. High infection rate of Trichophyton verrucosum in calves from Central Italy. Zoonoses Public Health, 56(2): 59-64.

Radostits, O.M., Gay, C.C., Blood, C.D. and Hinchcliff, K.W. 2000. Vet. Med., a text book of diseases of cattle, sheep, pigs, goats and horses. $9^{\text {th }}$ ed. NY. W.B. Saunders Co. Ltd., 960.

Rippon, J.W. 1988. Med. Mycol., $3^{\text {rd }}$ ed. Philadelphia, Saunders.

Swai, E.S. and Sanka, P.N. 2012. Bovine dermatophytosis caused by Trichophyton Verrucossum: a case report. Vet. World, 5(5): 297-300. doi: 10.5455/vetworld.2012.297-300

Takatori, K., Takahashi, A., Kawai, S., Ichijo, S. and Hasegawa, A. 1993. Isolation of Trichophyton verrucosum from lesional and non-lesional skin in calves. J. Vet. Med. Sci., 55(2): 343-344.

Wabacha, J.K., Gitau, G.K., Bebora, L.C., Bwanga, C.O., Wamuri, Z.M. and Mbithi, P.M. 1998. Occurrence of dermatophytosis due to Trichophyton verrucosum in dairy calves and its spread to animal attendants. J. S. Afr. Vet. Asso., 69(4): 172-173.

Weitzman, I. and Summerbell, R.C. 1995. The dermatophytes. Clin. Microbiol. Review, 8: 240-259.

\section{How to cite this article:}

Subha Ganguly, Parveez Ahmad Para and Praveen Kumar Praveen. 2017. Investigation of Dermatophytosis from the Skin Scrapings Collected from a Cow: A Case Study. Int.J.Curr.Microbiol.App.Sci. 6(3): 640-643. doi: https://doi.org/10.20546/ijcmas.2017.603.074 